\begin{abstract}
BACKGROUND: Interleukin-1 (IL-1), an inflammatory cytokine whose levels are elevated in inflamed mucosa, causes part of its effect on intestinal epithelial cells (IEC) through inducing ceramide production. Aim: To study the role of nuclear factor-kB (NF-kB), a pro-inflammatory and anti-apoptotic factor, in IL-1treated IEC.

Methods: NF-кB activity and levels of apoptotic proteins were assessed by electrophoretic mobility shift assay and RNA-protection assay, respectively. Results: IL-1 and ceramide, which have been shown to partially mediate IL-1 effects on IEC, activated NF$\kappa B$ levels significantly. This activation was due to a decrease in IKB- $\alpha$ and IкB- $\beta$ protein levels. Moreover, the ratio of mRNA levels of anti-apoptotic to proapoptotic proteins was significantly increased in IL-1treated IEC.

Conclusion: NF-кB may play a key role in the regulation of the expression of pro-inflammatory and/or apoptotic genes in inflammatory bowel disease, making this protein an attractive target for therapeutic intervention.
\end{abstract}

Key words: Nuclear factor- $\kappa \mathrm{B}$, Interleukin-1, Inflammatory bowel disease, Inflammation, Intestinal epithelial cells

\section{Regulation of nuclear factor- $\kappa B$ in intestinal epithelial cells in a cell model of inflammation}

\author{
Fadia R. Homaidan ${ }^{1, C A}$, Iman Chakroun ${ }^{1}$ and \\ Marwan E. El-Sabban ${ }^{2}$
}

${ }^{1}$ Department of Physiology and ${ }^{2}$ Department of Human Morphology, American University of Beirut, Faculty of Medicine, Beirut, Lebanon

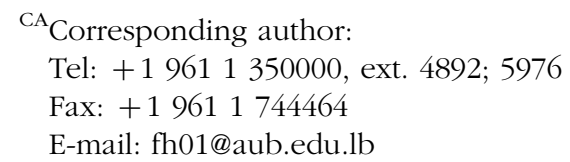

(IL-1) have been shown to be elevated in the mucosa of patients with inflammatory bowel disease. These cytokines possess diverse biological functions that include cell proliferation, inflammation and apoptosis. They contribute to activation of intestinal epithelial cells (IEC) activation as well as the activation of immune cells that get recruited after the inflammatory insult. We have shown that in IEC, IL-1 activates sphingomyelinase, an enzyme that catalyzes the hydrolysis of sphingomyelin to ceramide. ${ }^{10}$ In contrast to what has been observed in many cell types, however, ceramide did not induce apoptosis in IEC, neither did IL-1, but rather induced the synthesis of cyclooxygenase-2 (COX-2) leading to increased levels of pro-inflammatory mediators such as prostaglandin $\mathrm{E}_{2} \cdot{ }^{11} \mathrm{NF}-\kappa \mathrm{B}$ consensus regions have been shown to be present on the COX-2 promoter region and these regions have been shown to be involved in COX-2 mRNA induction by cytokines. ${ }^{12}$ Moreover, $\mathrm{NF}-\kappa \mathrm{B}$ seems to possess a significant anti-apoptotic role. ${ }^{13,14}$ Indeed, some known pro-apoptotic extracellular signals can induce NF- $\kappa \mathrm{B}$ that in turn induces the expression of genes that are anti-apoptotic. ${ }^{14}$ Mediators that can induce NF- $\kappa \mathrm{B}$ could therefore protect against apoptotic elimination of affected cells. Interestingly, this anti-apoptotic role of $\mathrm{NF}-\kappa \mathrm{B}$ has only been described for Rel-A but not for c-Rel or p50, which possess pro-apoptotic and anti-proliferative properties. $^{14,15}$ as tumor necrosis factor (TNF)- $\alpha$ and interleukin-1 
In this study we investigate the effects and mechanism of action of IL-1 and/or ceramide in

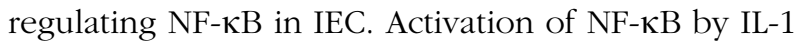
may be responsible for the lack of apoptosis observed in cells treated with IL-1 and/or ceramide. ${ }^{11}$

\section{Materials and methods}

\section{Materials}

Human recombinant IL- $1 \alpha$ was obtained from Immunex (Seattle, Washington, USA). Bromophenol blue, coomassie blue R-250, alkaline phosphataseconjugated goat anti-rabbit IgG, polyvinylidene difluoride (PVDF) membrane, sodium dodecyl sulfate (SDS), glycine tris, glycerol, $2-\beta$-mercaptoethanol, and $\gamma-{ }^{32} \mathrm{P}$ ATP were from Amersham Pharmacia Biotech (UK). Fetal bovine serum albumin and bovine serum albumin, penicillin and streptomycin, Dulbecco's Modified Eagle's Medium (DMEM), pyruvate, non-essential amino acids, goat serum and Earl's balanced salt solution were from Gibco Laboratories (Invitrogen, Carlsbad, California, USA). Acrylamide and $N^{\prime}, \quad N^{\prime}$-bis-methylene-acrylamide were from BioRad (California, USA), ammonium persulfate, $N, N, N^{\prime}, N^{\prime}$, Tetramethylethylenediamine (TEMED), chloroform, ethylenediamine tetraacetic acid (EDTA), Ethylene glycol-bis-(2-aminoethyl)$N, N, N^{\prime}, N^{\prime}$-tetraacetic acid (EGTA), methanol, acetic acid, isopropanol, dithiothreitol, imidazole, $\mathrm{LiCl}$, and etoposide were from Sigma (St Louis, Missouri, USA). $\mathrm{N}$-acetyl sphingosine (C2 ceramide) and ZLL (Z-leuleu-leu-CHO), a proteasome inhibitor, were purchased from BioMol (Plymouth Meeting, Pennsylvania, USA). RNA protection Kits and templates were obtained from BD Pharminegen (San Diego, California, USA). The multi-probe RPA template mapo-2 was used and it contained probes for the following mRNA: anti-apoptotic proteins bcl-2, bcl-w and bcl-xl, and pro-apoptotic proteins bad, bax, bak and bfl-1, and the housekeeping genes L-32 and GAPDH.

\section{Antisera}

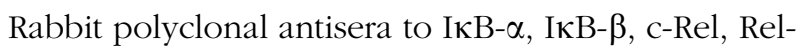
$\mathrm{A}, \mathrm{NF}-\kappa \mathrm{B}$ p $50, \mathrm{NF}-\kappa \mathrm{B}$ consensus oligonucleotide, luminol reagents, ECL marker and anti-rabbit $1 \mathrm{gG}$ horseradish peroxidase (HRP)-conjugate subunit were purchased from Santa Cruz Biotechnology (Santa Cruz, California, USA).

\section{Methods}

\section{Cell culture}

Murine intestinal epithelial cell 1 ine Mode- $\mathrm{K}^{16}$ was obtained from Dr P.B. Ernst (University of Texas,
Medical Branch, Galveston, Texas, USA). Mode-K cells were maintained in DMEM (low glucose) containing 10\% fetal bovine serum (FBS), $10 \mathrm{mM}$ sodium pyruvate, and non-essential amino acids. T84 cells, human colonic cell line, were grown in DMEM/F-12 medium supplemented with 10\% FBS. Cell viability was measured using the trypan blue exclusion assay.

Preparation of homogenate. Cells were trypsinized, centrifuged at $200 \mathrm{~g}$, and washed in phosphate-buffered saline (PBS) twice. The cells were then resuspended in PBS: $2 \times$ electrophoresis sample buffer (SB), ratio 1:1. The sample buffer consisted of $0.25 \mathrm{M}$ Tris $-\mathrm{HCl}(\mathrm{pH}$ 6.8), 4\% w/v SDS, 20\% v/v glycerol and $0.1 \%$ bromophenol blue. Samples were then boiled for $5 \mathrm{~min}$ and stored at $-80^{\circ} \mathrm{C}$.

\section{Nuclear extract preparation}

Cells were harvested and collected by centrifugation at $200 \mathrm{~g}$ for $10 \mathrm{~min}$ and washed once with PBS. Cells were lysed by rapid freezing in ethanol/dry ice and thawed by resuspension in a hypotonic ice-cold buffer containing $10 \mathrm{mM} \mathrm{KCl}, 1.5 \mathrm{mM} \mathrm{MgCl}_{2}, 1 \mathrm{mM}$ dithiothreitol (DTT), and $10 \mathrm{mM}$ Hepes. The nuclei were centrifuged at $1250 \mathrm{~g}$ for $10 \mathrm{~min}$ at $4^{\circ} \mathrm{C}$ and the nuclear pellets were gently extracted in a hypertonic solution containing $0.4 \mathrm{mM} \mathrm{NaCl}, 1.5 \mathrm{mM} \mathrm{MgCl}_{2}, 0.2$ mM EDTA, 1 mM DTT, 0.5 mM PMSF, 20 mM Hepes and $25 \%$ glycerol, for $30 \mathrm{~min}$ at $4{ }^{\circ} \mathrm{C}$, and then centrifuged for $20 \mathrm{~min}$ at $20,000 \mathrm{~g}$ to collect the nuclear proteins in the supernatant. The supernatant was diluted with $30 \mu \mathrm{l}$ of buffer containing: $50 \mathrm{mM}$ $\mathrm{KCl}, 20 \%$ (v/v) glycerol, $0.2 \mathrm{mM}$ EDTA, $1 \mathrm{mM}$ DTT, $0.5 \mathrm{mM}$ PMSF and $20 \mathrm{mM}$ Hepes, and stored at $-70^{\circ} \mathrm{C}$. Protein concentrations were determined using the Bio-Rad assay.

\section{Western blotting}

Total protein extracts were run on a $12 \%$ SDSpolyacrylamide gels. Gels were transferred to PVDF membranes overnight at $4^{\circ} \mathrm{C}$. Following transfer, membranes were washed with PBS containing 0.1\% Tween 20 (TPBS) and blocked with 5\% non-fat dry milk for $1 \mathrm{~h}$ at room temperature. Antibodies were then added in TPBS and incubated for $2 \mathrm{~h}$ at room temperature. Unbound antibodies were washed three times with TPBS and the anti-rabbit IgG HRPconjugate was added at 1:5000 dilution for $1 \mathrm{~h}$ at room temperature. The membranes were washed and incubated with luminol reagents and then exposed to autoradiography.

\section{Electrophoretic mobility shift assay}

NF- $\kappa \mathrm{B}$ consensus oligonucleotide was end-labeled with $\gamma-{ }^{32} \mathrm{P}$ ATP using T4 polynucleotide kinase. The 
hybridization reaction was performed using 10-20 $\mu \mathrm{g}$ of nuclear extract, $1 \mu \mathrm{g}$ of poly(dI.dC), $1 \mu \mathrm{g}$ of poly (dN6) as a non-specific competitor, and $10 \mu \mathrm{g}$ of bovine serum albumin in $20 \mathrm{mM}$ Hepes, $50 \mathrm{mM} \mathrm{KCl}$, $1 \mathrm{mM}$ EDTA and $5 \mathrm{mM}$ DTT. The reaction was diluted with water to a v/v ratio of 1:20 of the labeled probe. The mixture was incubated for $30 \mathrm{~min}$, then stopped by adding $6 \mu \mathrm{l}$ of $15 \%$ Ficoll solution containing the indicator dyes bromophenol blue and xylene cyanol. The reaction mixture (20 $\mu \mathrm{l}$ of each sample) was electrophorized on a 5\% non-denaturating polyacrylamide gel. The gel was transferred to Whatman filter paper, dried at $80^{\circ} \mathrm{C}$ under vacuum for $2 \mathrm{~h}$ and processed for autoradiography at $-80^{\circ} \mathrm{C}$ overnight. The specific NF- $\kappa \mathrm{B}$ band was determined by competition experiments using a mutant oligonucleotide that has lost its ability to bind to the transcription factor. Subunit specificity was determined using specific antibodies to the NF- $\kappa \mathrm{B}$ components (anti Rel-A, p50 and c-Rel) in the incubation step, which results in a supershift of the specific band due to the bound antibody.

\section{RNase protection assay}

Radioactive RNA probes were synthesized from DNA templates using T7 RNA polymerase and radioactive UTP as a substrate. The reaction was terminated after $1 \mathrm{~h}$ incubation at room temperature by the addition of DNase. The labeled RNA probes were extracted once with phenol:chloroform-isoamyl alcohol and once with chloroform-isoamyl alcohol. The probes were then precipitated in equal volume of $4 \mathrm{M}$ ammonium acetate and 5 volumes of ice-cold absolute ethanol, incubated at $-80^{\circ} \mathrm{C}$ for $30 \mathrm{~min}$, centrifuged at full speed for $15 \mathrm{~min}$ at $4^{\circ} \mathrm{C}$ in a microcentrifuge, washed once with 90\% ethanol, allowed to air-dry and then solubilized in hybridization buffer and quantified using a scintillation counter. RNA samples $(2-20 \mu \mathrm{g})$ were dried under vacuum and hybridized with the probe overnight.

Unhybridized RNA were digested using RNase A and the reaction was terminated by the addition of Proteinase K. Hybridized RNA were then extracted using phenol:chloroform-isoamyl alcohol, precipitated in ammonium acetate and absolute ethanol, washed once with 90\% ethanol and then air-dried. The pellets were solubilized in loading buffer (supplied by the manufacturer) and were ran on a $5 \%$ acrylamide-urea gel using $0.5 \times$ tris borate-EDTA buffer (containing $45 \mathrm{mM}$ tris-borate, and $1 \mathrm{mM}$ EDTA, pH 8.0) as a running buffer, dried and exposed to autoradiography. Yeast tRNA was used as a negative control.

\section{Results}

\section{IL-1 targets the NF- $\kappa \mathrm{B}$ pathway}

To establish whether IEC are functionally coupled to biological signals that lead to the activation of NF- $\mathrm{BB}$ by IL-1, cells were treated with IL-1 at different concentrations and time periods, and the NF- $\mathrm{BB}$ DNA binding activity was measured in nuclear extracts by eletrophoretic mobility shift assay using a NF- $\kappa \mathrm{B}$ consensus oligonucleotide. We first confirmed the constitutive expression of $\mathrm{NF}-\kappa \mathrm{B}$ in Mode$\mathrm{K}$ cells. Two positive complexes were detected by the radiolabeled NF- $\kappa \mathrm{B}$ consensus oligonucleotide (Fig. 1). These complexes were not changed in the presence of a mutant oligonucleotide (data not shown).

IL-1 has been shown to activate the sphingomyelin metabolic pathway, which will cause increased accumulation of ceramide in IEC. ${ }^{10}$ Ceramide acts as a second messenger in IEC and seems to mediate, at least in part, the effects of IL-l observed on IEC function. Thus the effect of ceramide on NF- $\kappa B$ in the presence or absence of IL-1 was tested. Treatment of IEC by IL-1 and/or ceramide caused a significant increase in NF- $\kappa \mathrm{B}$ levels in Mode-K cells (Fig. 2). Supershift assays using anti-p50 and c-Rel-specific antibodies showed little variation in the amount of the DNA-bound proteins with the various treatments, while Rel-A-containing heterodimers (activated NF$\kappa \mathrm{B}$ state) were supershifted, indicating that Rel-A is the major subunit that is translocated to the nucleus after cell activation by IL-1.

\section{Regulation of IKB subunits by IL-1 \\ Effect of $I L-1$ and ceramide on $I_{\kappa} B \alpha$ protein levels}

We next examined the effect of IL-1 on the activation of $\mathrm{I} \kappa \mathrm{B}$ to determine which subunit is responsible for
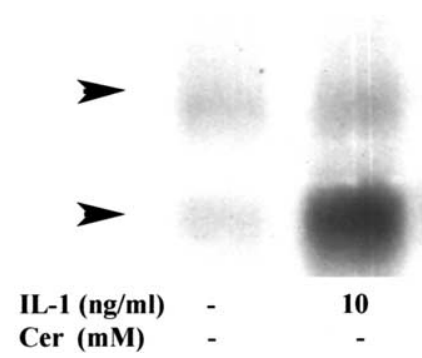

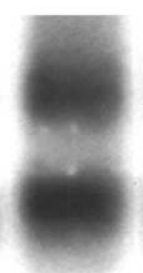

30

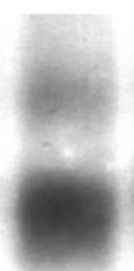

10

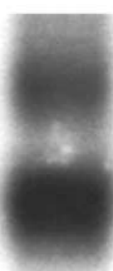

FIG. 1. Constitutive expression of NF-KB in Mode-K cells. In the second and third lane, as indicated, are shown increased expression of NF-KB in IL-1-treated cells $(10 \mathrm{ng} / \mathrm{ml}$ and $30 \mathrm{ng} /$ $\mathrm{ml}$, respectively) for $24 \mathrm{~h}$. In the last two lanes are shown increased expression of NF-kB in ceramide-treated cells (10 and $30 \mu \mathrm{M}$, respectively) for $24 \mathrm{~h}$. Equivalent amounts of nuclear extract from IEC were prepared and analyzed for NF$\kappa \mathrm{B}$ binding activity with a ${ }^{32} \mathrm{P}$-labeled oligonucleotide probe containing NF- $\kappa B$ binding sites. This experiment is representative of six. 


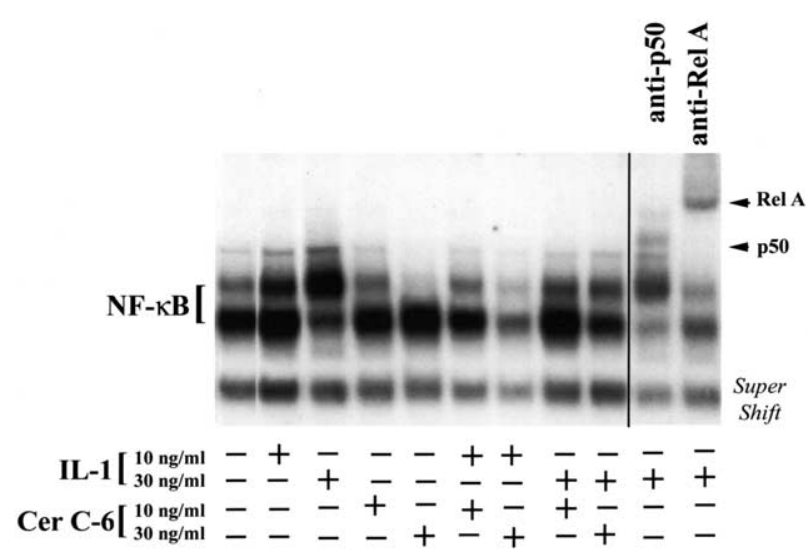

FIG. 2. Regulation of NF- $\mathrm{KB}$ activity by IL-1 and ceramide in IEC. Treatment of IEC by IL-1 and ceramide individually or in combination caused a significant increase in NF- $\kappa B$ levels in Mode-K cells. Supershift analysis of nuclear extract from cells incubated with rabbit antibody directed towards the p65 subunit (lane 10) or p50 subunit (lane 11) of NF-kB. Equivalent amounts of nuclear extract from IEC were prepared and analyzed for NF-KB binding activity with a ${ }^{32} \mathrm{P}$-labeled oligonucleotide probe containing NF- $\mathrm{KB}$ binding sites. Supershift assays using anti-p50-specific antibodies showed little but significant variation in the amount of the DNA-bound proteins, while Rel-A containing heterodimers (activated NF-KB state) were greatly supershifted, indicating that Rel-A is the major subunit that is translocated to the nucleus after cell activation by IL-1.

binding and sequestering NF- $\mathrm{KB}$ in the cytoplasm in different IEC lines, Mode-K and T-84 (Figs. 3 and 4 , respectively). The decrease in IкB levels releases Rel$\mathrm{A}$ and allows its translocation. IL-1 and ceramide caused a significant decrease in I $\mathrm{K} \alpha \alpha$ levels (both time and concentration dependent) with a significant decrease occurring at around $4 \mathrm{~h}$ with both treatments.

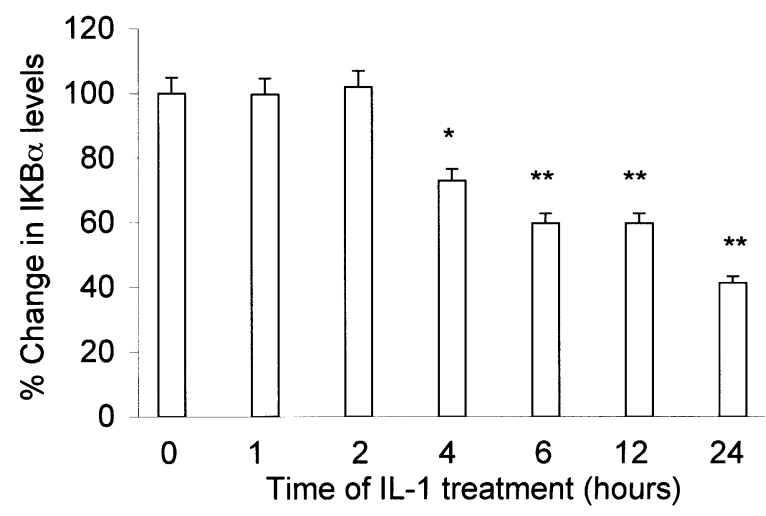

FIG. 3. Inhibition of IKB $\alpha$ levels by IL-1 $(30 \mathrm{ng} / \mathrm{ml})$ treatment for different time periods in Mode-K cells using western blot analysis of cytoplasmic extracts from IL-1-treated IEC. Expression of $\operatorname{I\kappa B} \alpha$ was visualized using $І \kappa \mathrm{K}$ - $\alpha$-specific polyclonal antibody. To confirm equal protein loading the membrane was stripped and reprobed with actin antibody. The bands were quantified using the Molecular Dynamics Storm 860 System (Molecular Dynamics, Sunnyvale, California, USA) using ImageQuant software. The density of the band equivalent to $I \kappa B \alpha$ levels in control untreated cells was set at $100 \%$ and the rest of the bands were calculated as a percentage of the control. ${ }^{*} p<0.05,{ }^{*} p<0.005 ; p$ value represents the comparison of the effect of IL- 1 on IKB $\alpha$ levels as compared with untreated control $(n=4)$.

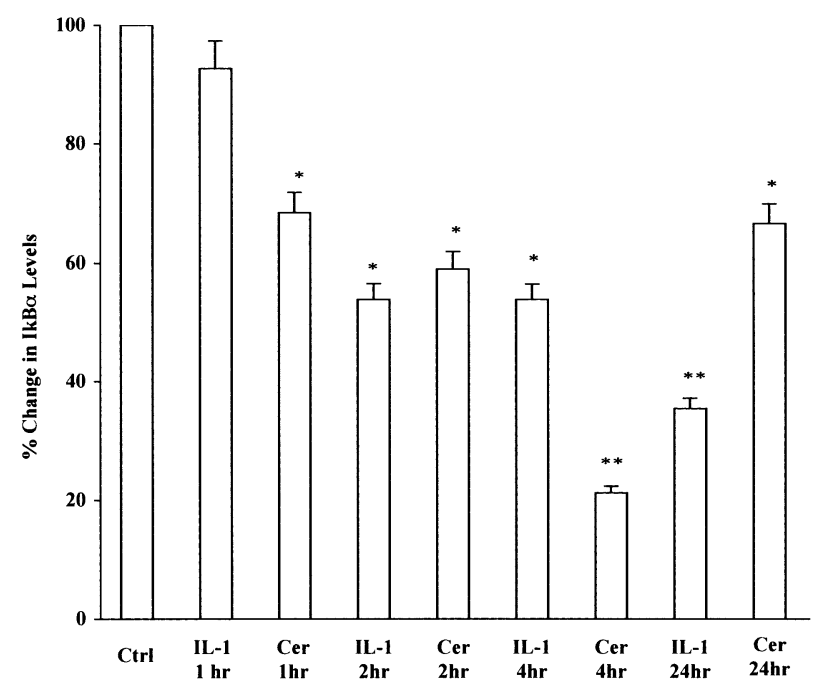

FIG. 4. Inhibition of $\mathrm{I} \kappa \mathrm{B} \alpha$ levels by IL-1 $(30 \mathrm{ng} / \mathrm{ml})$ and ceramide $(10 \mu \mathrm{M})$ treatment for different time periods in T84 cells using western blot analysis of cytoplasmic extracts from IL-1-treated and/or ceramide-treated IEC. Expression of $I \kappa B \alpha$ was visualized using I $\mathrm{KB} \alpha$-specific polyclonal antibody. To confirm equal protein loading the membrane was stripped and reprobed with actin antibody. The bands were quantified using the Molecular Dynamics Storm 860 System (Molecular Dynamics) using ImageQuant software. The density of the band equivalent to $\mathrm{I} \kappa \mathrm{B} \alpha$ levels in control untreated cells was set at $100 \%$ and the rest of the bands were calculated as a percentage of the control. ${ }^{*} p<0.05$, $* * p<0.005 ; p$ value represents the comparison of the effect of IL-1 on I $\mathrm{K} B \beta$ levels as compared with untreated control $(n=4)$.

\section{Effect of IL-1 and ceramide on $I_{\kappa} B \beta$ protein levels}

IL-1 and ceramide also induced a decrease in the levels of IкB $\beta$ levels in T-84 cells. The decrease, which was time (Fig. 5) and concentration dependent (data not shown), was maximal around $1 \mathrm{~h}$ with both treatments. The decrease observed in the levels of I $\kappa \mathrm{B} \alpha$ that was maximal at $4 \mathrm{~h}$ for IL-1 $(10 \mathrm{ng} / \mathrm{nl})$ and ceramide $(10 \mu \mathrm{M})$ was much greater than that observed with Iк-B $\beta$ for the same treatment $(80 \%$ decrease at $4 \mathrm{~h}$ versus $40 \%$ at $1 \mathrm{~h}$ in ceramide-treated cells, for example). This suggests that both IкB $\alpha$ and

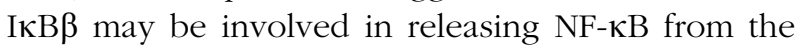
cytosolic complex to translocate into the nucleus; however, the effect of treatment on I $\mathrm{I} B \beta$ proceeds that of IкB $\alpha$. Similar results were obtained in Mode-K cells (data not shown).

\section{Effects of $I L-1$ and ceramide on $I \kappa B \varepsilon$ protein levels}

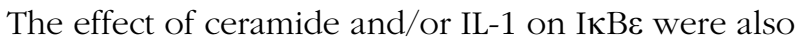
investigated. Neither treatment had any significant

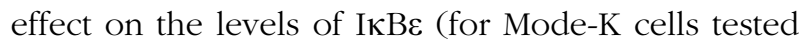
up to 24 h; Fig. 6) in either IEC line used, suggesting that it is not involved in the action of IL- 1 on NF- $\mathrm{\kappa B}$ activation. 


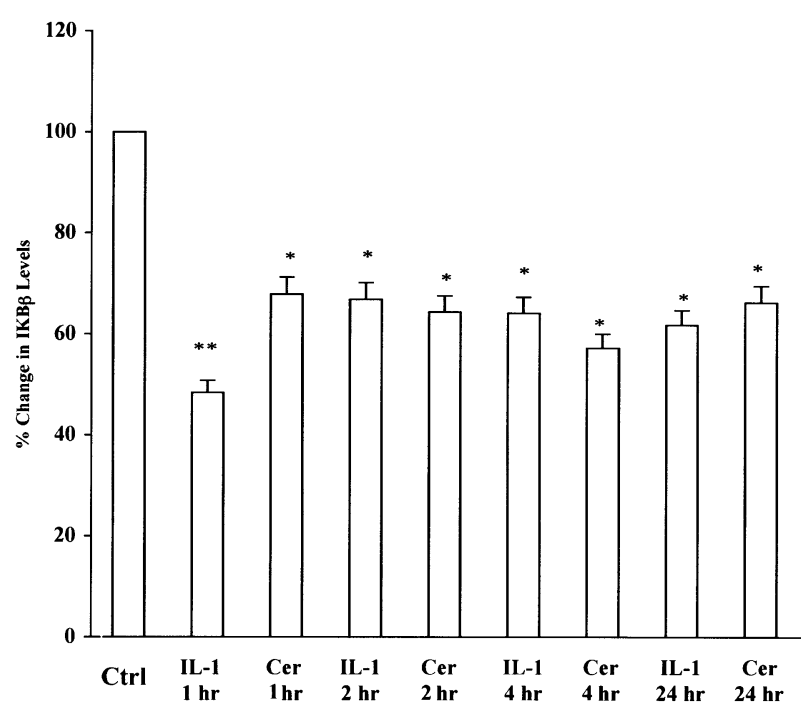

FIG. 5. Inhibition of IL- 1 on IKB $\beta$ levels by IL-1 $(30 \mathrm{ng} / \mathrm{ml})$ and ceramide $(10 \mu \mathrm{M})$ treatment in T-84 cells. Westem blot analysis of cytoplasmic extracts from IL-1-treated and/or ceramide-treated IEC. Expression of $I \kappa B \beta$ was visualized using I $\mathrm{\kappa} \beta \beta$-specific polyclonal antibody. To confirm equal protein loading the membrane was stripped and reprobed with actin antibody. The bands were quantified using the Molecular Dynamics Storm 860 System (Molecular Dynamics) using ImageQuant software. The density of the band equivalent to $I \kappa B \alpha$ levels in control untreated cells was set at $100 \%$ and the rest of the bands were calculated as a percentage of the control. ${ }^{*} p<0.05,{ }^{*} p<0.005 ; p$ value represents the comparison of the effect of IL- 1 on IKB $\beta$ levels as compared with untreated control $(n=4)$.

\section{Effects of $I L-1$ and ceramide on $I_{\kappa} B \alpha$ and $I_{\kappa} B \beta$ protein levels in the presence of $Z L L$}

ZLL is a potent and selective reversible proteasome inhibitor. It inhibits NF- $\kappa \mathrm{B}$ activation by preventing IкB degradation. Cells were treated with ZLL for different time periods before IL-1 or ceramide treatment, and the levels of $\operatorname{I\kappa } \mathrm{B} \alpha$ and $\operatorname{I\kappa } \mathrm{B} \beta$ were measured (Fig. 6). ZLL reversed the effect induced by IL-1 or ceramide on both I $\mathrm{KB}$ levels, thus preventing their degradation, and subsequently no translocation of $\mathrm{NF}-\kappa \mathrm{B}$ was observed. These data

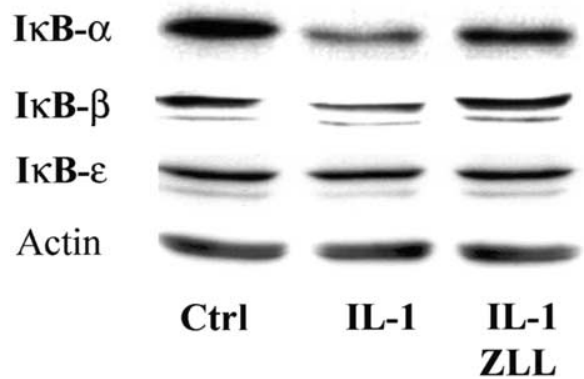

FIG. 6. Western blot analysis of cytoplasmic extracts showing the effects of IL-1 treatment $(30 \mathrm{ng} / \mathrm{ml})$ on the different $I \kappa B$. Inhibition of $I \kappa B \alpha$ and/or $I \kappa B \beta$ ubiquitination by ZLL reverses the effects of IL-1. There was no effect of IL-1 on $I \kappa B \varepsilon$ levels in Mode-K cells. Expression of $I_{\kappa} B$ was visualized using specific polyclonal antibodies. To confirm equal protein loading the membrane was stripped and reprobed with actin antibody. suggest therefore that translocation of $\mathrm{NF}-\kappa \mathrm{B}$ is dependent on the activation of proteasome that leads to the degradation of $I \kappa \mathrm{B} \alpha$ and $\mathrm{I} \kappa \mathrm{B} \beta$, thus freeing NF$\kappa \mathrm{B}$ to translocate to the nucleus for its action on activating different genes.

\section{Regulation of mRNA levels of apoptotic proteins by IL-1 treatment}

Using the RNA protection assay, the mRNA levels of apoptotic proteins were shown to be regulated by IL1 treatment. The mRNA levels of the anti-apoptotic proteins bcl-x and blc-w were increased while bcl-2 was unchanged; and the levels of the pro-apoptotic proteins bax, bak and bad were significantly reduced (Fig. 7). Similar results were obtained when cells were treated with ceramide. These data provide supportive evidence that IL-1 and/or ceramide do not induce apoptosis in intestinal epithelial cells and, rather, they feed into the prostanoid synthetic pathway through the induction of COX-2. ${ }^{11}$

\section{Discussion}

Apoptosis is a highly conserved evolutionary event crucial for normal development and homeostasis. Deregulated cell death has been associated with disease entities such as cancer ${ }^{17}$ and cardiovascular disease. ${ }^{18}$ Cells defective for NF- $\mathrm{KB}$ signaling were found to be more sensitive to apoptotic-inducing signals than normal wild-type cells, ${ }^{19,20}$ suggesting an anti-apoptotic role for NF- $\mathrm{NB}$. NF- $\kappa \mathrm{B}$ is a transcription factor involved in the regulation of many genes and is activated in response to a wide variety of stimuli including inflammation, viral and bacterial infections

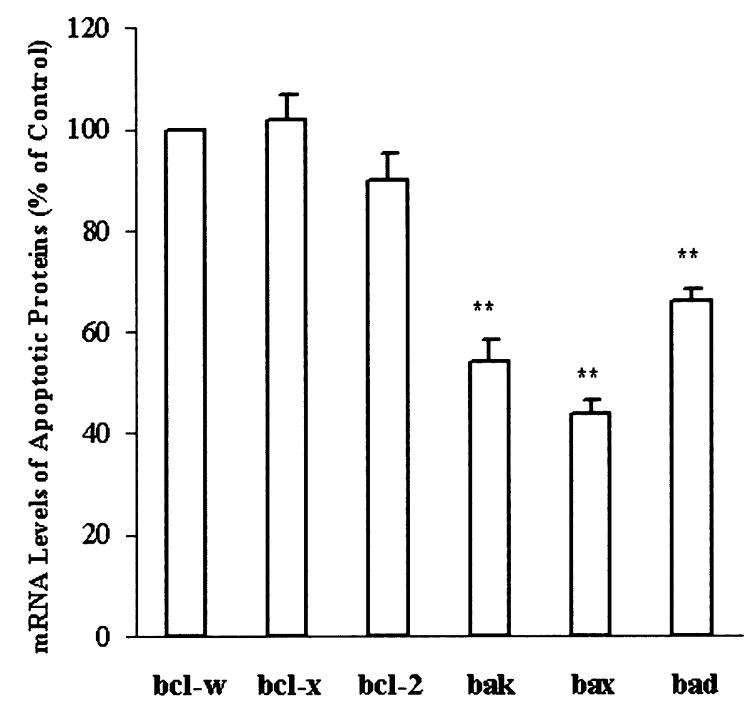

FIG. 7. mRNA levels of the anti-apoptotic proteins bcl-w, bcl$x$, bcl-2 and of pro-apoptotic proteins bak, bax and bad were measured in IL-1-treated Mode-K cells using the RNA protection assay. 
and stress factors. ${ }^{21}$ In particular, NF- $\mathrm{KB}$ has been shown to modulate the expression of pro-inflammatory cytokines, chemokines, immune receptors, adhesion molecules, and enzymes that generate mediators of inflammation. ${ }^{2}$ Activation of NF- $\mathrm{\kappa B}$ involves the dissociation of the Rel-A (p65) subunit from inhibitory proteins, mainly IкB $\alpha$, and its translocation from the cytoplasm to the nucleus, where it dimerizes with the p50 or c-Rel subunits and interacts with specific target genes. Activation of Rel-A or c-Rel containing NF- $\mathrm{KB}$ dimers results in the transcriptional stimulation of genes that are important for cell proliferation. NF- $\mathrm{\kappa B}$ also possesses a significant anti-apoptotic role. ${ }^{13,14}$ Indeed, the pro-apoptotic extracellular signals can also induce NF- $\mathrm{KB}$ that in turn induces the expression of genes that are antiapoptotic. ${ }^{14}$ We have previously shown that IL-1 and ceramide did not cause any increase in apoptosis in Mode-K intestinal epithelial cells. ${ }^{11}$ In this report, we show that treatment of cells with IL-1 caused activation of NF- $\mathrm{KB}$ and that this activation was completely dependent on its dissociation from the inhibitory

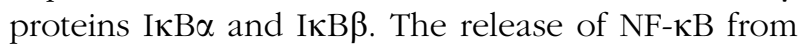

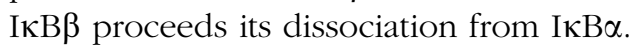

The increase in the ratio of anti-apoptotic to proapoptotic mRNA provides an explanation for the lack of induction of apoptosis in IL-1-treated and/or ceramide-treated IEC. Both stimulators feed into the prostanoid synthetic pathway through the induction of COX- $2,{ }^{11}$ whhich is thought to be due to activating $\mathrm{NF}-\kappa \mathrm{B}$ and translocation Rel-A to the nucleus where it can then bind on the COX-2 gene and induce its synthesis.

Mediators that can induce NF- $\mathrm{\kappa B}$ could therefore protect against apoptotic elimination of affected cells. Interestingly, this anti-apoptotic role of NF-KB has only been described for Rel-A but not for c-Rel or p50, which possess pro-apoptotic and anti-proliferative properties. ${ }^{14,15}$ This study shows that, upon activation of NF- $\kappa B$, Rel-A was the subunit that was translocated preferentially from the cytoplasm to the nucleus, where it is capable of dimerizing with the p50 or c-Rel subunits and interacts with specific target genes, some of which are apoptotic proteins. Using the RNA protection assay we were able to show that in IL-1-treated or ceramide-treated IEC, the message levels of anti-apoptotic proteins were significantly increased while those of the pro-apoptotic proteins levels were significantly decreased. This correlated well with what we have observed earlier in IL-1treated IEC where it was shown that the protein levels of bcl-x were increased while protein levels of bax were significantly reduced. ${ }^{11}$ Inhibition of NF- $\mathrm{KB}$ activation and subsequent translocation have been shown to promote apoptosis in tumor cells such as multiple myeloma cells. ${ }^{22}$ This was achieved using a proteasome inhibitor PS-341, which prevents the degradation of IkBs by the proteasomes and hence

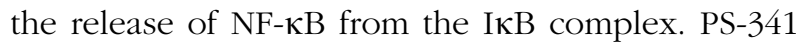
has also been recently used in clinical trials to resolve different types of malignancies. ${ }^{23,24}$

Activation of NF- $\mathrm{NB}$ is an important event in numerous inflammatory processes of the gastrointestinal tract. Induction of this transcription factor has been reported in Helicobacter pylori gastritis, ${ }^{25}$ inflammatory bowel disease, ${ }^{26}$ and pancreatitis. ${ }^{27}$ Recently, it has been shown that protein kinase C, intracellular calcium and activation of $\mathrm{NF}-\mathrm{\kappa B}$ are crucial for the induction of the COX-2 gene in the parietal cells in response to carbachol stimulation. ${ }^{28}$ Earlier reports have stated that ceramide is a major second messenger for TNF- $\alpha$-induced NF- $\kappa \mathrm{B}$ activation, ${ }^{29,30}$ while others have not observed any role for ceramide in I $\mathrm{K} B \alpha$ degradation. ${ }^{31}$ Ceramide was capable of activating NF- $\mathrm{KB}$ to the same extent as IL-1, providing more evidence that IL-1 causes some of its effects through the activation of the sphingomyelin pathway. ${ }^{10,11}$ Neither IL-1 nor ceramide induced apoptosis in IEC but both induced COX-2 synthesis leading to increased levels of prostaglandin $\mathrm{E}_{2} \cdot{ }^{10,11}$ The COX-2 gene contains consensus regions for NF$\kappa \mathrm{B}$ that have been shown to be important for the induction of COX-2 mRNA levels by cytokines. ${ }^{12}$ In human alveolar epithelial cells, ${ }^{32}$ activation of mitogen-activated protein kinases by ceramide contributes to the TNF- $\alpha$ signaling that occurs downstream of neutral sphingomyelinase activation and results in the stimulation of IKB kinase (IKK1/2) and NF-KB in the COX-2 promotor, followed by initiation of COX-2 expression. Pro-inflammatory cytokines activate the IKK complex that phosphorylates the NF- $\mathrm{KB}$ inhibitors, triggering their conjugation with ubiquitin and subsequent degradation ${ }^{33,34}$ via a non-lysosomal, ATP-dependent proteolytic proteasome. Freed NF$\kappa \mathrm{B}$ dimers translocate to the nucleus and induce target genes, such as COX-2, which catalyzes the synthesis of pro-inflammatory prostaglandins, in particular prostaglandin $E_{2}$. At late stages of inflammatory episodes, however, COX-2 directs the synthesis of anti-inflammatory cyclopentenone prostaglandins, suggesting a role for these molecules in the resolution of inflammation.

ACKNOWLEDGEMENTS. This project is supported by grants from the American University of Beirut Medical Practice Plan, the Lebanese National Research Council, and the Third World Academy of Sciences.

\section{References}

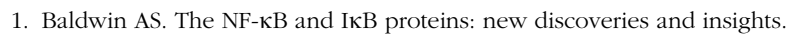
Annu Rev Immunol 1996; 14: 649-683.

2. Barnes PJ, Karin M. Nuc1ear factor- $\mathrm{\kappa B}$ - a pivotal transcription factor in chronic inflammatory diseases. N Engl J Med 1997; 336: 1066-1071.

3. Baeuerle PA, Henkel T. Function and activation of NF- $\mathrm{KB}$ in the immune system. Annu Rev Immunol 1994; 12: 141-179.

4. Thonas D, Maniatis T. Identification of the rel family members required for virus induction of the human beta interferon gene. Mol Cell Biol 1995; 15: $152-164$

5. Thonas D, Maniatis T. NF kappa B: a lesson in family values. Cell 1995; 80: $529-532$ 
6. Finco TS, Baldwin AS. Mechanistic aspects of NF kappa B regulation: the emerging role of phosphorylation and proteolysis. Immunity 1995; 3 $263-272$.

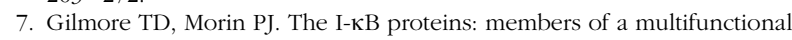
family. Trends Genet 1993; 9: 427-433.

8. Brown K, Gerstberger S, Carlson L, Franzoso G, Siebenlist U. Control of IкB- $\alpha$ proteolysis by site-specific, signal-induced phosphorylation. Science 1995; 267: 1485-1488.

9. Traenckner EBM, Pahl HL, Henkel T, Schmidt KN, Wilk S, Baeuerle PA.

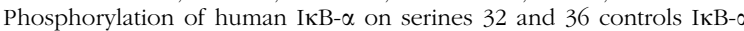
proteolysis and NF- $\mathrm{\kappa B}$ activation in response to diverse stimuli. $E M B O J$ 1995; 14: $2876-2883$

10. Homaidan FR, Chakroun I, Dbaibo GS, El-Assaad W, El-Sabban ME. IL-1 activates two phospholipid signaling pathways in intestinal epithelial cells. Inflamm Res 2001; 50: 375-381.

11. Homaidan FR, Chakroun I, EJ-Sibai M, Dbaibo GS, EI-Sabban ME. IL-1 stimulates ceramide levels without inducing apoptosis in intestinal epithelial cells. Mediat Inflamm 2002; 11: 39-45.

12. Yamamato K, Arakawa T, Ueda N, Yamamato S. Transcriptional role of nuclear factor $\kappa \beta$ and nuclear factor interleukin- 6 in the tumor necrosis factor $\alpha$-dependent induction of cyctoxygenase-2 in MC 3T3-E1 cells. $J$ Biol Chem 1995; 270: 31315-31320.

13. Beg AA, Sha WC, Bronson RT, Baltimore D. Embryonic lethality and liver degeneration in mice lacking the Rel-A component of NF-kappa B. Nature 1995; 376: 167-170.

14. Bauerle PA, Baltimore D. NF-kappa B: ten years after. Cell 1996; 87: $13-$ 20.

15. Abbadie C, Kaburn N, Boudi F, Smardova J, Stehelin D, Vandenbunder B, Enrietto PJ. High levels of c-re1 expression are associated with programmed cell death in the developing avian embryo and in bone marrow cells in vitro. Cell 1993; 75: 899-918.

16. Vidal K, Grosjean I, Revillard JP, Gespach C, Kaiserlian D. Immortalization of mouse intestinal epithelial cells by SV40-large T gene. Phenotypic and immune characterization of the Mode-K cell line. J Immunol Methods 1993; 166: 63-73.

17. Reed JC. Bcl-2 family proteins: regulators of apoptosis and chemoresistance in hematologic malignancies. Semin Hematol 1997; 34: 9-19.

18. Mustapha S, Kirshner A, De Moissac D, Kirshenbaum LA. A direct requirement of nuclear factor- $\mathrm{KB}$ for suppression of apoptosis in ventricular myocytes. Am J Physiol 2000; 279: H939-H945.

19. Van Atwerp DJ, Martin SJ, Kafri T, Green DR, Verma IM. Suppression of TNF-K-induced apoptosis by NF-KB. Science 1996; 274: 787-789

20. Wang CY, Mayo MW, Baldwin AS Jr. TNF- and cancer therapy-induced apoptosis: potentiation by inhibition of NF-КB. Science 1996; 274: 784787.

21. Jobin C, Sartor BR. The IkB/NF-kB system: a key determinant of mucosal inflammation and protection. Am J Physiol 2000; 278: C451-C462.
22. Hideshima T, Mitsiades C, Akiyama, et al. Molecular mechanisms mediating antimycloma activity of proteasome inhibitor PS-341. Blood 2003; 101: 1530-1534.

23. Aghajanian C, Soignet S, Dizon DS, et al. A phase I trial of the novel proteasome inhibitor PS341 in advanced solid tumor malignancies. Clin Cancer Res 2002; 8: 2505-2511.

24. Orlowski RZ, Stinchcombe TE, Mitchell BS, et al. Phase I trial of the proteasome inhibitor PS-341 in patients with refractory hematologic malignancies. J Clin Oncol 2002; 20: 4420-4427.

25. Keates S, Hitti Y, Upton M, Kelly C. Helicobacter pylori infection

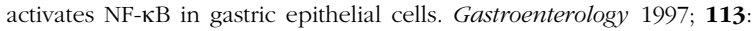
$1099-1109$

26. Wahl C, Liptay S, Adler G, Schmid R. Sulfasalazine: a potent and specific inhibitor of nuclear factor kappa B. J Clin Invest 1998; 101: 1163-1174.

27. Guvosky I, Guvoskaya A, Blinman T, Zaninovic V, Pandol S. Early NF- $\mathrm{kB}$ activation is associated with hormone-induced pancreatitis. Am J Physiol 1998; 275: G1402-G1414

28. Pausawasdi N, Ramamoorthy S, Crofford LJ, Askari FK, Todisco A. Regulation and function of COX-2 gene expression in isolated gastric parietal cells. Am J Physiol 2002; 282: G1069-G1078.

29. Schutze S, Potthoff K, Machleidt T, Berkovic D, Wiegman K, Kronke M. TNF activates NF-kB by phosphatidylcholine specific phospholipase Cinduced 'acidic' sphingomyelin breakdown. Cell 1992; 71: 765-776.

30. Reddy SAG, Chaturvedi M, Darnay BG, Chan H, Higuchi M, Aggarwal $\mathrm{BB}$. Reconstitution of nuclear factor $\mathrm{\kappa B}$ activation induced by tumor necrosis factor requires membrane-associated components. J Biol Chem 1994; 269: 25369-25372.

31. Zumbansen M, Stoffel W. Tumor necrosis factor $\alpha$ activates NFкB in acid sphingomyelinase-deficient mouse embryonic fibroblasts. J Biol Chem 1997; 272: $10904-10909$.

32. Chen CC, Sun YT, Chen JJ, Chang YJ. Tumor necrosis factor- $\alpha$-induced cyclooxygenase-2 expression via sequential activation of ceramidedependent mitogen-activated protein kinases, and ІкB kinase $1 / 2$ in human alveolar epithelial cells. Mol Pharmacol 2001; 59: 493-500.

33. Di Donato JA, Hayakawa M, Rothwarf DM, Zandi E, Karin M. A cytokineresponsive IкB kinase that activates the transcription factor $\mathrm{NF}-\kappa \mathrm{B}$. Nature 1997; 388: 548-554.

34. Zandi E, Chen Y, Karin M. Direct phosphorylation of IкB by IKK $\alpha$ and IKK $\beta$ : discrimination between free and NF-кB-bound substrate. Science 1998; 281: $1360-1363$.

\section{Received 3 June 2003 \\ Accepted 8 August 2003}




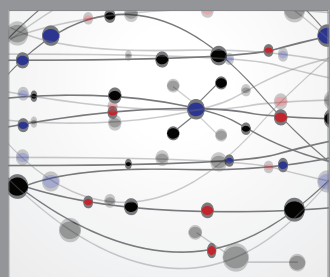

The Scientific World Journal
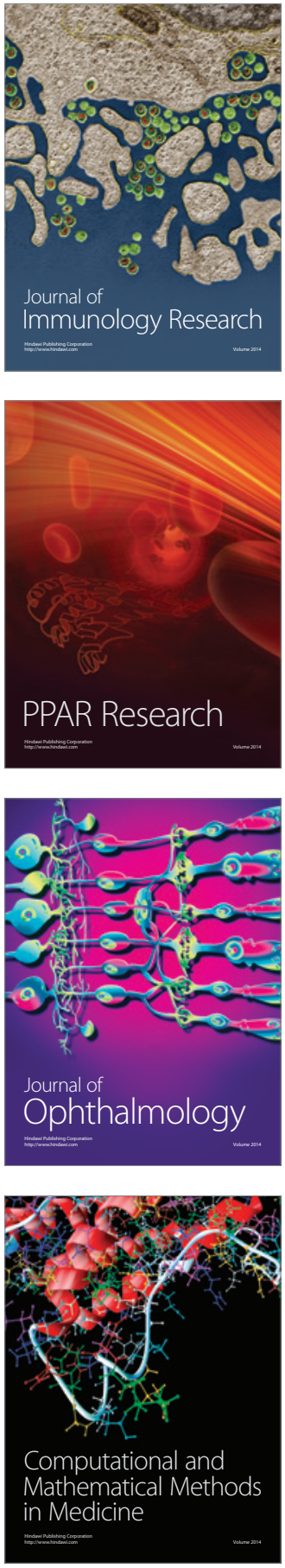

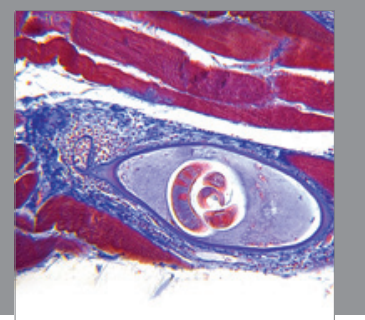

Gastroenterology

Research and Practice
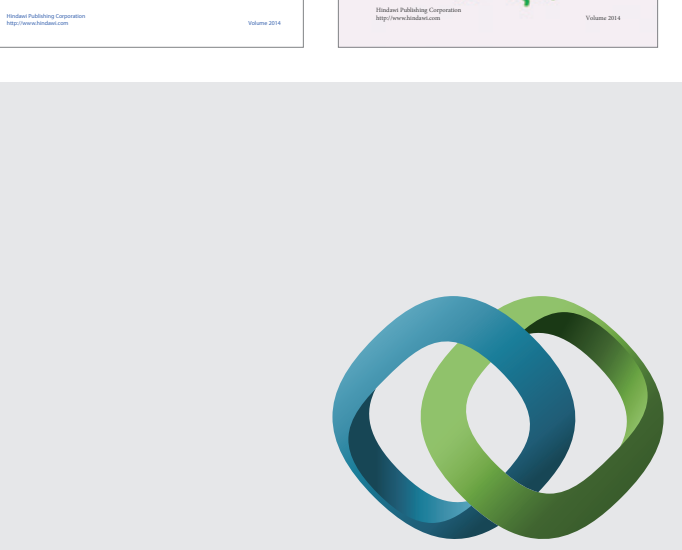

\section{Hindawi}

Submit your manuscripts at

http://www.hindawi.com
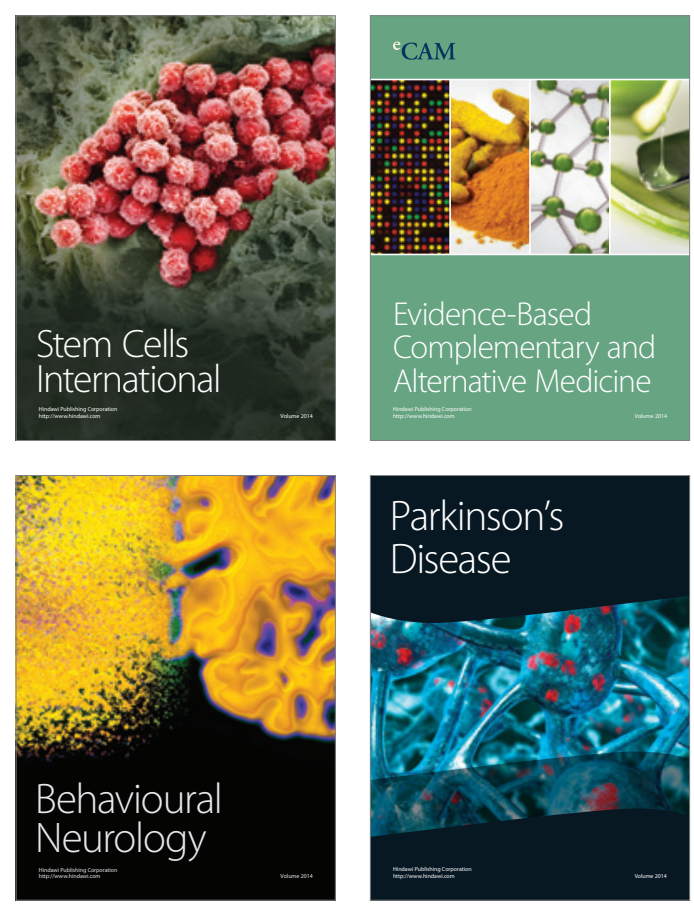

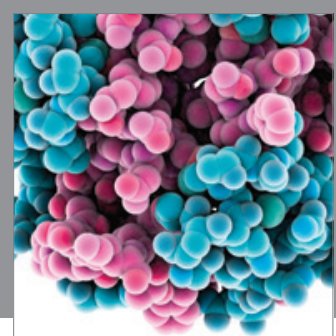

Journal of
Diabetes Research

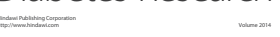

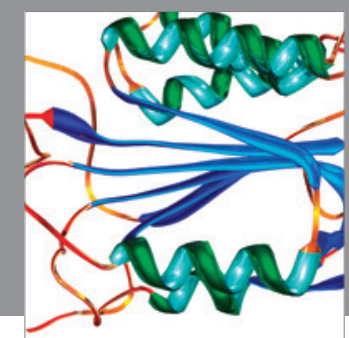

Disease Markers
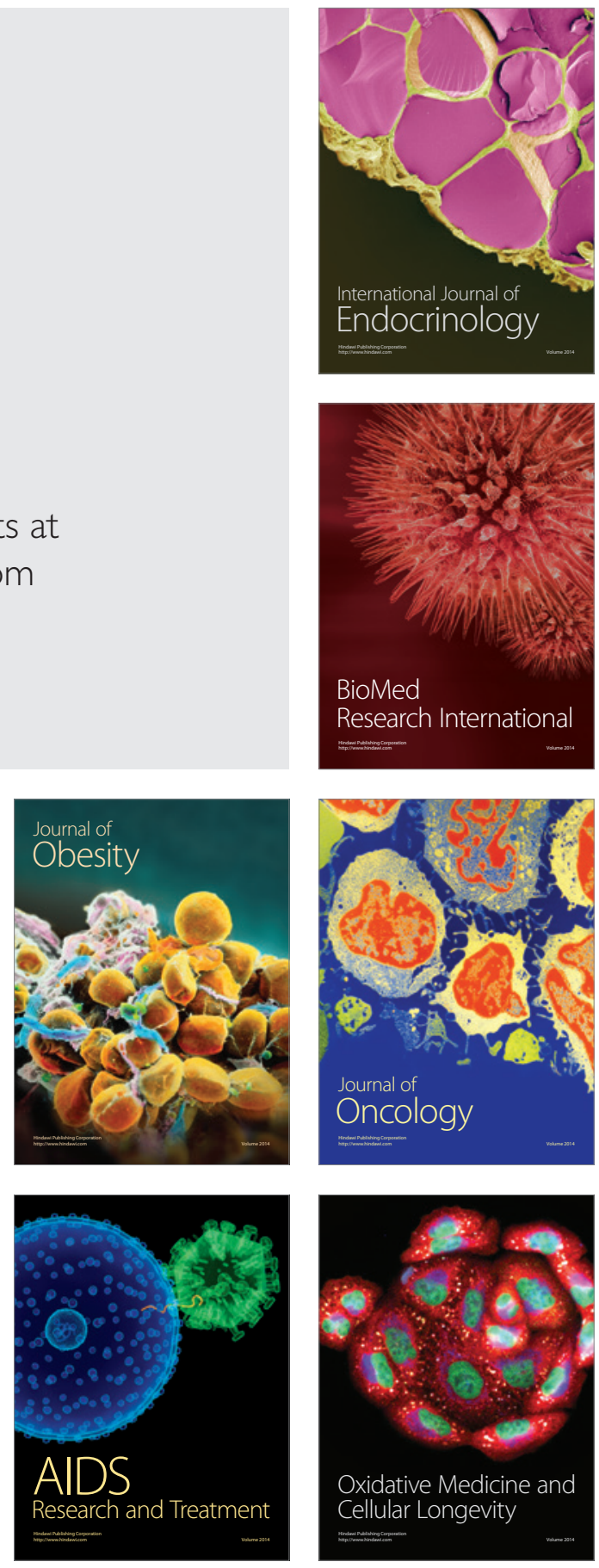